\title{
Correlation Between Mother's Role and Preparation of Teenage Girls in Facing Puberty Changeat Elementary School
}

\author{
Dina Putri Utami Lubis ${ }^{1}$, Vivi Nuryanti ${ }^{2}$ \\ **Nursing Programed, Institute of Health Science Yogyakarta, Indonesia ${ }^{1}$ \\ *Nursing Programed School Of Nursing Surya GlobalYogyakarta, Indonesia ${ }^{2}$
}

Email: utilubis@yahoo.com

\begin{abstract}
Introduction: During teenage will experience many changes both physically and psychologically. To deal with the changes that occur, teenage require readiness, both physically and psychologically. The role of the mother is one of the factors that affects readiness in facing the changes in puberty of the teenage. The purpose of this research was to know the correlation between the mother's role and the readiness of teenage girl in facing the change of puberty of 8 until 12 years old at the elementary school Methods: This research type was quantitative with descriptive correlational design using cross sectional approach. The number of samples used were 37 respondents. Sampling technique used in this research was the purposive sampling technique with the data analysis using chi square test. The study was done in August 2017.Results: From the statistical test results obtained p-value of 0.001 ( $\alpha<0.05)$ with a value of contingency of 0.485.Conclusions: There was a correlation between the mother's role and the readiness of adolescent girls in facing the change of puberty at class II and Vat the elementary school with correlation of both variables in strong and unidirectional category.
\end{abstract}

Keywords: Role of Mother, Readiness of Puberty, Changes of puberty

\section{INTRODUCTION}

Adolescence is a transitional period of. This period is regarded as a very important period in the life of a person specialized in the formation of individual personalities (Latifah, 2008). Teenagers tend to individuals who are in the teenage age range and puberty. Puberty means ongoing hormonal changes in early teens, adolescence may be prolonged (Padmomartono, 2014).

Generally the age limit for prepubertal period for women is 9-10 years while for the age limit of puberty is 11-15 years (World Health Organization [WHO], 2012). According to WHO (2015), globally adolescent birth rate is 44.1 out of 1000 women aged 15-19 years. The number of teenagers in the world today reaches approximately 1.2 billion and one in five people in this world are teenagers (WHO, 2012). In Indonesia alone, the population of women aged $10-15$ years is the highest in East Java province with the number of 1.944 .991 people and the Special Region of Yogyakarta ranks 22nd with the number as many as 148.857 people (Data Portal Indonesia, 2014).
According to the Indonesia Youth Survey Demographic and Health Survey (SDKIR) stated that as many as $13.3 \%$ of teenage girls do not know at all about physical changes during puberty, even $47.9 \%$ of teenage girls do not know the time of puberty ( National Population and Family Planning Agency (BKKBN), 2012). According to BKKBN in 2012 shows that the knowledge of adolescent girls about adolescent reproductive health is still very low. In this case, the role of a mother is very important especially during adolescence. However, some mothers are reluctant to discuss openly and share information about the things that happen when children experience puberty. Some mothers think that it is not worth talking about. These conditions will increase the sense of anxiety and mistrust in adolescents so that adolescents tend not ready in the face of puberty. The impact of such unpreparedness will cause various problems both physically and psychologically.mother's role as a source of information about adolescent development, especially at puberty, is expected to make children more ready to face changes in puberty, because in essence the changes that occur during 
puberty do not only occur physically in the form of changes in body shape and menstruation but also psychologically, still marked many teenagers who do not understand and understand the things that are done in the face of changes in puberty.

A mother must be prepared to accept that her child has passed through childhood and is now entering puberty.

Mother should have prepared herself with information on issues related to puberty, therefore the role of mother as a source of information is very important for the readiness of young women in the face of changes in puberty.

The purpose of this research was to know the correlation between the mother's role and the readiness of teenage girl in facing the change of puberty of 8 until 12 years old at the elementary school.

\section{METHODS}

The type of this research is nonexperimental quantitative. The research design used is descriptive correlational with cross sectional approach. This research was conducted at the elementary school. This research was conducted in August 2017. The population in this research is all students of class IV \& V at Elementary School that is as many as 62 people. The reason of sampling in grade IV and $\mathrm{V}$ students. In this research sampling using nonprobability sampling technique that is purposive sampling, then the researchers take samples according to inclusion criteria that has obtained ethical clearance.

Data collection techniques namely primary data in this study in the form of data sourced directly from respondents. This primary data was obtained through a questionnaire that was distributed to the fourth and fifth grade students of SD NegeriBabarsari and interviews. Secondary data in this study were obtained from the Principal of Babarsari Elementary School, class IV and $\mathrm{V}$ guardians and theories from reference to journals made as a theoretical reference.

Data collection is done by distributing questionnaires to respondents. After all the data is collected, the researcher checks the complete identity of the respondent's data and ensures that all answers are filled in all and according to instructions. Data processing is done by editing, which is a process of checking or checking data that has been successfully collected from the field, because there is a possibility that the data that has been entered does not meet the requirements or not needed. Then the data is coded, which is the giving of certain codes on each data that belongs to the same category. Then tabulating, the value data is collected and grouped carefully and regularly into tables to facilitate data processing so that tables are easy to analyze.

In this study, researchers analyzed data using computer aids through the SPSS program. Data analysis was performed by univariate and bivariate analysis.

The researcher submitted permission to the Babarsari Public Elementary School principal to conduct research at the place. Then the researchers conducted a preliminary study at SD NegeriBabarsari. A preliminary study was conducted on principals and students of grades IV and V at SD NegeriBabarsari which took place on March 6, 2017.

\section{RESULTS}

Based on the data table 1 of the characteristic data for the age of 37 respondents the overall data is on the respondents have an age range of 8-12 years. Meanwhile, the grade level of 37 respondents of the most data or the majority of respondents are in grade $\mathrm{V}$ as 18 female students $(48.6 \%)$ while for class IV there are 15 students $(51.4 \%)$.

Based on table 2 shows that the role of mothers good categorized either 33 respondents $(89.2 \%)$ and the lowest data 4 respondents with less category.

Based on table 3, it is found that respondents who have category have good readiness in facing puberty counted 31 respondents $(83,8 \%)$ and respondent with category have less readiness in face of change of puberty period 6 responden $(16,2 \%)$.

Analysis of the relationship between the role of mothers with the readiness of adolescent girls in the face of puberty changes in grade IV and V students at SD Negeri Babarsari 
Table. 1 Respondent's Characteristics

\begin{tabular}{llll}
\hline & Characteristics & Frequency (n) & Percentage (\%) \\
\hline 1. & Age (Years Old) & 37 & 100 \\
2.12 & & \\
2. & Class Level & 18 & 48,6 \\
a. Class IV & 19 & 51,4 \\
b. Class V & 37 & 100 \\
\hline
\end{tabular}

Primary Data 2017

Table. 2 Univariate Analysis Role of Mother Corelation with Young Women Preparation in Facing the Change of Puberty Period In Grade IV and V Students at SD Negeri Babarsari Depok Sleman

\begin{tabular}{llll}
\hline & Mother's role & Frequency $(\mathbf{n})$ & Percentage $\mathbf{( \% )}$ \\
\hline 1. & Good & 33 & 89,2 \\
2. & Less & 4 & 10,8 \\
Total & & 37 & 100 \\
\hline
\end{tabular}

Primary Data 2017

Table. 3 Univariate Analysis Role of Mother Categorized with Young Women Preparation in

Facing the Change of Puberty Period In Grade IV and V Students at SD Negeri Babarsari Depok Sleman

\begin{tabular}{llll}
\hline & Mother's role & Frequency $(\mathrm{n})$ & Percentage $(\%)$ \\
\hline 1. & Good & 31 & 83,8 \\
\hline 2. & Less & 6 & 16,2 \\
\hline Total & & 37 & 100 \\
\hline
\end{tabular}

Primary Data 2017

Table. 4 Bivariate Analysis Role of Mother Corelation with Young Women Preparation in

Facing the Change of Puberty Period In Grade IV and V Students at SD Negeri Babarsari

Depok Sleman

\begin{tabular}{llllllllll}
\hline Mother's & \multicolumn{8}{c}{ Readiness faces changes in puberty } \\
\cline { 2 - 9 } Role & Good & Less & Total & & $X^{2}$ count & Cont. Coeff & $\rho$ Value \\
& F & $\%$ & f & $\%$ & F & $\%$ & & & \\
Good & 30 & $90,9 \%$ & 3 & $9,1 \%$ & 33 & $100 \%$ & 11.407 & 0.485 & 0.001 \\
Less & 1 & $25 \%$ & 3 & $75 \%$ & 4 & $100 \%$ & & & \\
Total & 31 & $83,8 \%$ & 6 & $16,2 \%$ & 37 & $100 \%$ & & & \\
\hline
\end{tabular}

Depok Sleman, based on Table 4, found that the value of chi square of 11.407 with a significant value of 0.001 this indicates that there is a significant relationship between the role of the mother with preparedness adolescent girls in the face of changes in puberty in class IV and $\mathrm{V}$ at Babarsari State Element is marked by Chi count $11.407<3.481$ and significance $0.001<0.05$. While the value of contingency coefficient of 0,485 shows that the relationship between the two variables is the role of the mother with the readiness of young women in the face of moderate puberty changes and positive values indicate that the correlation of both variables are unidirectional. These results indicate that the better the mother's role in providing information the better the adolescent's readiness in facing the period of pubertal changes.

\section{DISCUSSIONS}

Roles are defined as determinants of how a person should behave in that position. Viewed from the role of a mother there are several factors that influence the role of a mother that is (1) knowledge, the majority of 
well-informed mothers provide good reproductive health education as well (Suryoputro, et al, 2012). (2) Education Level, highly educated people will get more information because it will be exposed to media information and can easily access information from various media (Iswardani, 2016). (3) The availability of time, when a mother works with the availability of time to accompany the child is reduced then the mother's communication to the child in accompanying the transitional period will be reduced. (4) History of mental disorders in the family, children who have mothers suffering from mental disorders have unequal achievement with other children (Amalia, 2015). From the results of the research obtained with a significant relationship between the role of the mother with the readiness of adolescent girls in the face of puberty is also supported by research conducted by Purwati (2016) who examines the relationship of mother role in providing information with knowledge about menarche in adolescent age 10- 13 years old in Mojokerto Elementary School known the result that there is a relationship between the role of mother in providing information with adolescent knowledge about menarche in adolescent girls aged 10-13 years in SDN MojokariMojokertoMojokerto.

This is also in line with the research that has been done by Nova (2015) with title relationship of mother role as educator with readiness to face first menarche at SD Banyumanik 01 Semarang City got result of relation between mother role as educator with readiness face first menstruation with value of significance of $\mathrm{P}=0.044$.

This research is also supported by research conducted by Sari (2015) with title of mother role relationship with behavior of selfcare during menstruation at student of class VII at SMP Muhammadiyah 10 Yogyakarta, got result of mother role to his daughter in SMP Muhammadiyah 10 Yogyakarta majority in good category 34 students (69.4\%) and self-care behavior during menstruation were also in the good category of 33 students $(67.3 \%)$. There is a relationship between mother's role with self-care behavior during menstruation with significance value $\mathrm{P}=0.000$.
Based on the researcher's exposure and compared with the existing research, the researcher concludes that most of the role of mother having good category and the readiness of adolescent girl in facing puberty is also in good category, it happened because some factors influencing mother role that is knowledge, , time availability and family history of mental disorders. While the researcher's assumption on the readiness of adolescent girl in facing change of puberty is not same between one child with other child because of the many factors that influence the readiness itself that is parent role especially mother, self concept and social environment. However, based on the research results obtained frequency of adolescence readiness in the face of changes in puberty is largely in the good category, it is not separated from the mother's role factors that affect.

\section{CONCLUSIONS}

There is a correlation of mother role with the readiness of teenage girl in facing change of puberty. The limitations of researchers found during the study took place are role of mothers in this study is only a source of information, while there are still many roles for mothers in preparing children who come to puberty and role of the mother as information is only taken with a questionnaire filled in by students and not crosschecked with parents.

Based on the research that has been done by the researchers, the suggestions that can be given are: For Nursing Science, this study is expected to contribute and add literature for nursing science, especially nursing maternityas a reference for providing health counseling to mothers who have children aged 8 to 11 years old.

For teenage, is expected to better understand and even increase the knowledge they have by searching for more sources of information.

For Parents, it is expected that parents have more effective and open communication in children, especially mothers, including in terms of maturity development of the reproductive system.

For Further Researcher, as the basis of scientific development to carry out advanced 
research related to mother role and readiness of adolescent girl in facing change of puberty. In addition, it is expected that further research should be continued with other independent variables such as the relationship of father role with the readiness of adolescent puberty to face changes in puberty.

Recommendations for health workers, especially maternity nurses, to carry out nursing care starting from the assessment stage to primary school evaluation.

\section{REFERENCES}

Amalia, I. (2015). 'Gambaran Perkembangan Pada Anak yang Memiliki Ibu Menderita Gangguan Jiwa'. Skripsi. Fakultas Pendidikan Universitas Negeri Semarang.

Findings:http://lib.unnes.ac.id/diaksespada tanggal 7 januari 2017 pukul 12.30 WIB.

BKKBN. (2012). 'Kajian Profil Remaja (10-24 Thn). Jakarta: BKKBN Jakarta

Fajri, $\quad$ N. (2015). 'HubunganPeranIbudenganPersiapanRem ajaMenghadapiMasaPubertas di SMP Negeri 1 Juli Kecamatan Juli Kabupaten Biruen'.Skripsi.Universitas Sumatera Utara. Findings: http://repository.usu.ac.id/handle/ diakses pada tanggal 8 November 2016 pukul 20.35 WIB.

Iswardani, R. (2016). 'Hubungan Antara Tingkat Pendidikan Dengan Pengetahuan Tentang Hak-Hak Reproduksi Pada WUS di Desa Candirejo Ungaran Barat Semarang'. KTI. Akademi Kebidanan Ngudi Waluyo. Findings: $\quad$ http:// perpusnwu.web.id/karyailmiah/documents /4905.pdfdiaksespadatanggal 10 januari 2017 pukul 12.30 WIB.

Latifah, M. (2008). 'Karakteristik Remaja'.Findings:

http://www.ChildDevelopment.com diakses pada tanggal 18 November 2016pukul 18.50 WIB.

Notoatmodjo, S. (2010). 'Metodelogi Penelitian Kesehatan'. Jakarta: Rineka Cipta

Nova, F. S. (2015). 'Hubungan Peran Ibu Sebagai Pendidik Dengan Kesiapan
Menghadapi Menstruasi Pertama (Menarche) Pada Siswi SD Banyumanik Kota Semarang. Skripsi. STIKes Ngudi Waluyo Ungaran. Findings: http://perpusnwu.web.id/karyailmiah/docu ments/4259.pdf diakses pada 28 Agustus 2017 pukul 09.10 WIB.

Padmomartono, S. (2014). 'Konseling Remaja'. Yogyakarta: PenerbitOmbak.

Portal Data Indonesia. (2010). Data Jumlah Penduduk Berdasarkan Usia. Findings:http://data.go.id/dataset/jumlahpenduduk-berdasarkan-jenis- kelamindan-kelompok-usia diakses pada tanggal 18 November 2016 pukul 20.30 WIB.

Purwati, H. (2016). 'Hubungan Peran Ibu Dalam Memberikan Informasi Dengan Pengetahuan Tentang Menarche Pada Remaja Putri Usia 10-13 Tahun di SD Menanggal Kecamatan Mojosari Mojokerto'. Skripsi. STIKes Bina Sehat PPNI Mojokerto. Findings: ejournal.stikes-

ppni.ac.id/index.php/keperawatan-binasehat/article/view/307/307

diaksespadatanggal 27 Agustus 2017 pukul 20.50 WIB.

Sari, A. F, M. (2015). 'Hubungan Peran Ibu dengan Perilaku Perawatan Diri Saat Menstruasi Pada Siswi Kelas VII Di SMP Muhammadiyah 10 Yogyakarta. Skripsi. STIKes 'Aisyah Yogyakarta. Findings: http://opac.unisayogya.ac.id/347/1/AYU\% 20FITRIYA\%20MUSTIKA\%20SARI_20 1410104107 NASKAH\%20PUBLIKASI. pdfdiaksespadatanggal 27 Agustus 2017 pukul 11.37 WIB.

Suryoputro, A, Shaluhiyah, Z \& Meilani, N. (2012). 'Perilaku Ibu dalam Memberikan Pendidikan Seksualitas pada Remaja Awal', Jurnal Kesehatan Masyarakat Nasional, vol. 8, no. 8. Yogyakarta: Politeknik Kesehatan Kementerian Kesehatan.

World Health Organization (WHO). 2012. Batasan Usia Remaja Menurut WHO. Findings:http://www.who.int/gho/publicati ons/world_health_statistics/EN_WHS201 2 Full.pdf\&sa=U\&ved=OahUKEwj2jOiw diakses pada tanggal 18 November 2016 pukul 19.40 WIB. 